Vol. 7: 54-66, April 2021

ISSN: 2392-4535 (Print), 2392-4543 (Online)

DOI: https://doi.org/10.3126/jnarc.v7i1.36921

\title{
Biocontrol of Soil Borne Pathogen of Potato Tuber Caused by Rhizoctonia solani through Biosurfactant based Bacillus strain
}

\author{
Touseef Hussain ${ }^{1 @}$, Abrar Ahmad Khan ${ }^{1}$ and M.A. Khan ${ }^{2}$
}

${ }^{1}$ Plant Pathology Section, Department of Botany, Aligarh Muslim University, Aligarh-202002, India; (D): http://orcid.org/0000-0002-3325-0423; @: Hussaintouseef@yahoo.co.in; AAK: Khanaba2009@gmail.com ${ }^{2}$ Deptartment of Soil Science and Agricultural Chemicals, ICAR-Indian Agricultural Research Institute, New

Delhi110012, India; malimuddin@gmail.com

Received 9 September, 2019, Revised 18 November, 2020, Accepted 05 April, 2021, Published 30 April, 2021

Scientific Editors: Subash Subedi, Beda Nand Chaudhary

Copyright $(2021$ NARC. Permits unrestricted use, distribution and reproduction in any medium provided the original work is properly cited.

The authors declare that there is no conflict of interest.

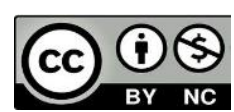

OPEN ACCESS

Licensed under the Creative Commons Attribution NonCommercial 4.0 International (CC BY-NC 4.0)

\section{ABSTRACT}

Black scurf disease is a major problem for cultivation of potato worldwide that is managed by synthetic agrochemicals, that are increasing environmental pollution as well as residue in farm produce also. Therefore, now a day use of bio-agents for managing black scurf is attractive feature and need of the hour. A promising bio surfactant OD02 isolate, was isolated from oil contaminated soil, utilizing its secondary metabolite after preliminary biosurfactant screening tests. Furthermore, this strain exhibited positive test with haemolytic activity, emulsification index, oil spreading test, molecular characterization with 16S rRNA universal primers revealed that the strain belongs to Bacillus group, that was further chemically characterized using TLC, exhibiting reddish pink colour as lipopeptide and demonstrated antagonistic activity against Rhizoctonia solani under in vitro using dual culture $(45 \pm 0.30 \%)$ and at $3 \%$ concentration under food poisoning method. Bacillus subtilis HussainT-AMU strain is very effective against phytopathogen $R$. solani and can be more explored in future diseases management strategies.

Keywords: Biological Control, Black scurf, Bacillus spp., Rhizoctonia solani, Soil borne

सारांश

आलुको कालो खोस्टे रोग विश्वमा आलु खेतीको एउटा प्रमुख समस्या हो र यो रोग बीउ आलुबाट सर्ने प्रवृत्तिको भएकोले यसलाई कृत्रिम कृषि रसायनको प्रयोगबाट व्यवस्थापन हुँदै आएको छ जसले गर्दा वातावरणीय प्रदुषण बढ़ने तथा फार्म उत्पादहरुमा विषादी अवशेष रहने समस्या रहेकोछ। त्यसैले हालका दिनहरुमा जैविक पदार्थहरुको प्रयोगद्वारा कालो खोस्टे रोगको व्यवस्थापन गर्ने तरिकाहरु बढी रुचाइएका छन् । तेलले विगारेको माटोबाट आइसोलेट गरी उक्त आइसोलेटको द्वितीय जैविक मेटावोलाइटलाई निकाली पूर्व स्क्रीनिड गरी एक प्रचलित जैविक सर्फेक्टेन्ट $\mathrm{ODO} 2$ आइसोलेट गरिएको थियो । यस सर्फेक्टेन्टलाई हेमोलाइटिक गतिविधि, इमल्सिफिकेसन इन्डेक्स तथा तेलको वहाव परीक्षण साथै प्राइमर 16SrRNA सँगको यौगिक चारित्रिकरण गर्दा सकारात्मक नतिजा प्राप्त भएकोले यो सर्फेक्टेन्ट व्यासिलस समूहको हो भन्ने पुष्टि हुन्छ। साथै यसलाई थप TLC को प्रयोग गरी रासयनिक चारित्रीकरण गर्दा यसले लाइपापेप्टाइटको रातो गुलावी रंग दियो र टेष्टट्युवमा गरिएको डुअल कल्चरमा Rhizoctonia solani को गतिविधिहरुसँग विपरित गतिविधिहरु ( $४ \pm \pm O$ ३३०\%) र खाद्य विषादीकरण तरिकामा ३\% गाठा गतिविधि देखायो । कालो खोष्टे लगाउने R. solani जीवाणुको विरुद्धमा प्रयोग गर्न Bacillus subtilis HussainT-AMU प्रजाति बढी प्रभावकारी पाइयो जसलाई भविष्यमा यस्ता रोगहरु व्यवस्थापन गर्ने रणनीतिहरुमा उपयोग ल्याउन सकिन्छ ।

\section{INTRODUCTION}

Black scurf is an important fungal pathogen of potato (Solanum tuberosum L.) in the category of soil and tuber borne. Infected seeds are the main sources of infection (Durak 2016). Black scurf was reported in Maine in 1913 by Morse and Shapovalo in the Maine Agricultural Station Bulletin \#230, "The Rhizoctonia Disease of Potatoes" (https://extension.umaine.edu/publications/wp- 
content/uploads/sites/52/2020/06/2273-reviewed-2020.pdf) and subsequently spread to all the potato growing areas, affects potato development from emergence to harvest. In addition to the development of unsightly sclerotia or 'black scurf' on tubers, this affects marketability of the crop (Bakali and Martin 2006). It is distributed in India in different regions at different levels of severity and is a major disease problem in fields where potato is cultivated yearly in the same field (Khurana et al 1998, Arora 2012). The black scurf disease cause yield loss up to $25 \%$ in the hill while in plain, it cause about $10 \%$ yield loss (Sharma, 2015). Out of various strategies available for the disease's management, the chemical based strategies have been by far most dominating. Seed treatment with $3 \%$ boric acid has been identified as a safe and effective chemical treatment and has been recommended for the control of this disease (Arora 2005). Various methods of disease control, biological control agents, is the most preferred natural choice to manage plant diseases that can enhances crop yields by growth promoting attributes of environment friendly microorganisms (Kiewnick and Sikora 2006, Mohsin et al 2010, Hussain and Khan, 2020). Many researches showed that Bacillus strains can be used as biological control agents against R. solani infecting pepper (Ahmad et al 2003,), potato (Szczech et al 2006, Calvo et al 2010, Hussain and Khan, 2020), Tomato (Khedher et al 2015) plant, and so forth. Now a days, biosurfactant microbes are gaining very importance in plant protection. These biosurfactants are surface active compounds produced by a variety of microorganisms their mode of action, in biological control involves the formation of channels in the cell wall and perturbations of the cell surface of the pathogen (Raaijmakers et al 2006). The best-known biosurfactants in biological control are cyclic lipopeptides and rhamnolipids (Stanghellini and Miller 1997). The concept of biosurfactants involved in the biological control activity of plant pathogens by the bacterial strains was also proved by the work done by (Anjaiah et al 1998, Tambong and Hofte 2001). Surfactins and iturins are lipopeptides produced by Bacillus subtilis Cohn (Kavitha et al 2012). In previous studies (Pusey et al 1988 and Pusey and Wilson 1984) showed that Bacillus subtilis could be a potentially better biocontrol agent for the crop diseases produced by harmful fungi and bacteria. Gokte and Swarup (1988), Hussain et al 2020a also showed that cells and spores of B. subtilis were toxic to nematodes Meloidogyne incognita, Heterodera cajani, Heterodera avenae and Anguina tritici. The biocontrol methods are attracting more importance now a day, due to their safe environmental friendly in nature. In our study we focused on the oil contaminated soil near Paradwip port, isolated a new biosurfactant strain, preliminary characterization and identify its antagonistic activity against the pathogen Black scurf is reported here.

\section{MATERIALS AND METHODS}

\section{Survey and Sample Collection}

Soil samples mixed with crude oil/coal powder were collected (beneath $5 \mathrm{~cm}$ of surface) from near Paradwip port site, Paradwip, Odisha $\left(20^{\circ} 15^{\prime} 55.44^{\prime \prime} \mathrm{N}\right)$ during 2017. Soil samples were collected in clean plastic bags. These samples were used immediately to prevent any deterioration.

\section{Isolation of biosurfactant bacteria}

At plant pathology lab., Dept. Of Botany, AMU, Aligarh in 2017, five gram of oil contaminated soil sample was inoculated in $100 \mathrm{ml}$ minimal medium (Miller, 1972) and incubated at $37^{\circ} \mathrm{C}$, at $200 \mathrm{rpm}$ for $48 \mathrm{hrs}$. From that $100 \mathrm{ml}$ stock serial dilution technique was used for isolation of biosurfactant bacteria, $1 \mathrm{ml}$ from the soil suspension at $\left(10^{2}\right.$ to $\left.10^{7}\right)$ dilution was spread on each petri plate of RA2 agar medium (Himedia, Mumbai) and these plates were incubated at $37^{\circ} \mathrm{C}$ for $48 \mathrm{hrs}$ dark bacterial incubator. Morphologically different colonies were randomly picked/selected and purified on Nutrient agar medium plates (with $0.1 \%$ petrol mixed) (Shoeb 2006). The selected bacterial isolates were stored on Nutrient agar (Himedia, Mumbai) petri plates as well as on Nutrient agar slants (with $0.1 \%$ petrol mixed) slants and kept under $4^{\circ} \mathrm{C}$.

\section{Screening methods for biosurfactant activity}

The isolated bacteria were tested further for biosurfactant production through following methods:

\section{Penetration Assay (PA)}

This method relies on the phenomenon of silica gel entering the hydrophilic phase from hydrophobic paste much more quickly in the presence of biosurfactant which leads to a colour change (Walter et al 
2010). In this assay, the cavities of 96 well microtiter plate (Corning, USA) were filled with $150 \mu 1$ of a hydrophobic paste made up of oil (petrol) and silica gel. The paste was covered with $20 \mu l$ of oil. The $10 \mu 1$ of $1 \%$ safranin was added to $90 \mu 1$ of the culture supernatant. In the control, uninoculated medium was added instead of culture supernatant. This coloured supernatant was then placed on the surface of the paste. The upper phase changes from clear red to cloudy pink red within 15 minutes if biosurfactant is present. Biosurfactant free supernatant was turned cloudy but stayed red. Based on the results of qualitative screening tests, positive isolates showing good surfactant activity were selected for further studies.

\section{Oil Spreading Method (OSM)}

For this test, oil (Petrol) was layered over water in a petriplate $(9 \mathrm{~cm}) .10 \mu 1$ supernatant (from culture broth) was added to the surface of oil (petrol) as described by (Morikawa et al 2000). Occurrence of clear zone was an indication of biosurfactant production. Water drop was used as a negative control (Morikawa et al 1993).

\section{Haemolytic Activity (HA)}

The pure culture of bacterial isolates (24hrs) was streaked on the freshly Sheep blood agar plates (Potous Medium, New Delhi) and incubated at $37^{\circ} \mathrm{C}$ for $24-48 \mathrm{hrs}$ to assay haemolytic activity. Haemolytic activity was detected with the presence of a clear zone (Haemolysis) around bacterial colonies. The plates were visually inspected for clear zones of clearing around colonies (Satpute et al 2008).

\section{Emulsification Index (EI24\%)}

The emulsifying capacity was evaluated by an emulsification index. The EI24\% of samples was determined by adding $2 \mathrm{ml}$ of petrol and $2 \mathrm{ml}$ of the cell-free broth in test tube, vortexed at high speed for $2 \mathrm{~min}$ and allowed to stand for 24hrs. The percentage of emulsification index was calculated by using the following equation (Youssef et al 2004).

\section{EI24\% $=$ Height of emulsion formed $\times 100$ \\ Total height of solution}

\section{Isolation of Fungal pathogen}

The field collected infected tubers with black scurf of potato were surface sterilized by $0.25 \%$ Sodium hypochlorite for two minutes and extensively washed with sterile distilled water. The black sclerotia presented on the surface of potato were peeled and placed on petri plates containing potato-dextroseagar (PDA) and incubated at $26 \pm 2^{\circ} \mathrm{C}$ for $48-72 \mathrm{hr}$. Subsequently, grown fungal culture was purified by hyphal tip method and identified by compound microscopic. Pure culture of $R$. solani was preserved at $4^{\circ} \mathrm{C}$ in culture tubes and petri plates containing PDA for further study at department Plant pathology lab.

\section{PCR based 16S rRNA gene amplification and Sequencing}

The freshly inoculated $24 \mathrm{hrs}$ bacterial broth culture of OD02 was inoculated in sterilized nutrient broth ( $0.1 \%$ petrol mixed) used for DNA extraction. After 24 hrs bacterial DNA was extracted by CTAB method as follows: About $1.5 \mathrm{ml}$ culture cultivated on nutrient broth was centrifuged to obtain pellet. The pellet was suspended in $1.5 \mathrm{ml}$ Tris EDTA by vigorous pipetting to ensure proper distribution of the culture in TE buffer followed by centrifugation at $10,000 \mathrm{rpm}$ for $5 \mathrm{~min}$. This step was repeated by decanting and further addition of TE buffer followed by centrifugation. By discarding supernatant fresh TE buffer $(740 \mu \mathrm{l})$ was added along with $20 \mu \mathrm{l}$ Lysozyme $(100 \mathrm{mg} / \mathrm{ml})$ and mixed 6 well by incubating for $5 \mathrm{~min}$. at room temperature. After incubation, $40 \mu \mathrm{l}$ of $10 \%$ SDS was carefully added, followed by $8 \mu$ of proteinase $\mathrm{K}(10 \mathrm{mg} / \mathrm{ml})$ while mixed well. The total mixture was incubated for $1 \mathrm{hr}$ at $37^{\circ} \mathrm{C}$. The mixture was supplemented with $100 \mu \mathrm{l}$ of $5 \mathrm{M} \mathrm{NaCl}$ and mixed well. Then the addition of $100 \mu 1$ $\mathrm{CTAB} / \mathrm{NaCl}$ solution which was preheated at $65^{\circ} \mathrm{C}$ was done. Final mixture was incubated for reaction at $65^{\circ} \mathrm{C}$ in pre-adjusted water bath for $10 \mathrm{~min}$. After incubation, the mixture was supplemented with $0.5 \mathrm{ml}$ chloroform: isoamyl alcohol (24:1) and mixed well. Followed by mixing, tubes were spun down at maximum speed for $10 \mathrm{~min}$. at room temperature. Developed upper aqueous layer was transferred to a fresh tube. To aqueous layer $0.5 \mathrm{ml}$ phenol: chloroform: isoamyl alcohol (25:24:1) was added and 
mixed well. Liquid was then centrifuged at maximum speed for 10 min. at room temperature, while obtaining an upper aqueous layer was transferred to a fresh tube. It was added with 0.6 vol. of isopropanol kept initially in $-20^{\circ} \mathrm{C}$ and incubated at room temperature for $30 \mathrm{~min}$. followed by centrifugation at maximum speed for $15 \mathrm{~min}$., supernatant was decanted and pellet washed with $70 \%$ ethanol. It was centrifuged at maximum speed for 5 min. Supernatant was removed and pellet air dried

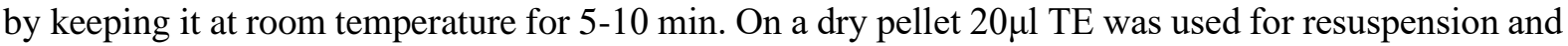
stored at $-20^{\circ} \mathrm{C}$ until further use. The successful isolation of genomes was analyzed on $0.8 \%$ agarose gel.

About 20ng of bacterial gDNA was used to amplify 16S rRNA gene applying following 16S Universal primers 16S (F) AGA GTT TGA TCC TGG CTC AG, (R) AAG GAG GTG ATC CAG CCG CA. The PCR amplifications of 16S rRNA gene of bacterial isolates were performed for the total of the $50 \mu 1$ reaction mixture. The amplification mixture comprised of $32.0 \mu 1$ nuclease freewater, $5.0 \mu 1$ PCR buffer $10 \mathrm{x}, 2.0 \mu \mathrm{dNTP}(10 \mathrm{mM}), 4.0 \mu \mathrm{l}$ forward primer $(10 \mu \mathrm{M}), 4.0 \mu \mathrm{l}$ reverse primer $(10 \mu \mathrm{M}), 1.0 \mu \mathrm{l} \mathrm{Taq}$ DNA polymerase enzyme $(1 \mathrm{U} / \mu \mathrm{l})$ and $200 \mathrm{ng}$ DNA template. The temperature range for $50 \mu \mathrm{l}$ each PCR reaction was programmed at the following conditions: initial denaturation of $3 \mathrm{~min}$. at $94^{\circ} \mathrm{C}$, denaturation of $1 \mathrm{~min}$. at $94^{\circ} \mathrm{C}$, primer annealing for $1 \mathrm{~min}$. at $54^{\circ} \mathrm{C}$, extension of $30 \mathrm{sec}$ at $72^{\circ} \mathrm{C}$, final extension for $5 \mathrm{~min}$. at $72^{\circ} \mathrm{C}$; total 30 cycles. The amplified PCR products were sent to the private firm for sequencing that was performed in ABI prism 3100 Genetic Analyzer (Applied Biosystems). The sequences were checked against the microbial nucleotide databases using BLASTN search algorithms (Mendez 2014) (http://www.ncbi.nlm.nih.gov/ BLAST).

\section{Phylogenetic analysis}

For the phylogenetics analysis, DND file obtained from CLUSTAL alignment was used for the phylogram built up by using the MEGA 6.06 software. In an output, built phylogram was documented close homology of the bacteria isolated (showcased with the accession number) with the best matched bacterial sequence and highlighted by marking in a Phylogram.

\section{Chemical characterization of biosurfactant}

Thin layer chromatography (TLC) analysis: The partially purified biosurfactant obtained from $B$. subtilis HussainT-AMU strain was characterized by TLC plate made up of aluminum sheet silica gel 60F24 plate (Merck) with solvent system using chloroform: methanol: acetic acid (75:15:2). Ninhydrin reagent was sprayed to confirm the type of biosurfactant (Anandraj et al 2010).

Evaluation of B. subtilis HussainT-AMU against $R$. solani: This novel bacteria B. subtilis HussainT$A M U$ is maintained at Dept. of Botany, Aligarh Muslim University, Aligarh was used for present study.

\section{Dual culture assay}

Bio-efficacy of B. subtilis HussainT-AMU was evaluated against R.solani in dual culture test. Mycelial discs $(5 \mathrm{~mm})$ were cut from the 2 to 3 days old cultures of $R$. solani with the help of a cork borer and placed in the petri plates containing sterilized potato dextrose agar at the periphery. The bioagents were streaked on the other side of petri plate at equal distance. All the petri plates were incubated at $28 \pm 2^{\circ} \mathrm{C}$, till the radial growth of control petri plates were full. Radial growth and percent inhibition of test pathogens was measured as per Vincet 1927, at different time intervals (24, 48, 72 and 96 hrs).

\section{Food-poisoning method}

The culture filtrate of B. subtilis HussainT-AMU was prepared as described by Tomar et al 2013, and were sterilized with $0.45 \mu \mathrm{m}$ filters and tested against R. solani. Different concentrations of culture filtrates $(0.25,0.5,1.0,2.0,3.0$, and 5.0\%) were used in food- poisoning method (Grover and Moore 1962). Calculated volume of the culture filtrate was added to the molten PDA medium and poured aseptically to the petri plates and allowed to solidify. Five $\mathrm{mm}^{2}$ of freshly growing (3-4 days) $R$. solani culture was placed at the centre of the petri dishes. Unamended medium served as the control. Three replications were maintained for each treatment. All the petri plates were incubated at $28 \pm 2^{\circ} \mathrm{C}$, till the radial growth of control petri plates were full. Radial growth of $R$. solani was measured at different intervals and inhibition percentage was calculated (Mohsin et al 2010). 


\section{RESULTS}

Isolation of bacteria from soil

Total, 12 unique different aerobic bacterial populations were isolated from crude oil/coal powder soil samples collected from Paradwip port, Odisha. Repeated streaking and sub-culturing of these bacterial isolates were purified and screened for the initial biosurfactant production bacteria test on specific growth media and after that for the biosurfactant production conformation tests was carried out. Those isolates which exhibited best biosurfactant activity were carried for further screening and were maintained at $4^{\circ} \mathrm{C}$.

\section{Screening for Biosurfactant production activity}

Our study showed that all the bacterial isolates producing biosurfactant activity display good emulsification with oil. The culture supernatant placed on the surface of the hydrophobic paste, resulted in colour change in upper phase from red to cloudy white with OD02 isolate only which was noted as positive test. Partial change in colour or appearance of red colour wells was observed in rest OD01,0310 isolates as shown in Figure 1. Overnight culture of OD02 isolated bacteria was centrifuged and added to oil (petrol) containing petri plate. OD02 isolate showed the clear zone $(2.3 \mathrm{~cm})$ by being able to displace the oil (petrol) around the colony indicating biosurfactant production Figure 2. Rest other $\mathrm{OD}(01,03-10)$ isolates showed partial activity (between $0.3-0.5 \mathrm{~cm})$. No clear zone was observed with control (water). The haemolytic activity was observed in only OD02 isolate, results showed positive haemolytic activity (complete clear zones of more than $2 \mathrm{~cm}$ ) in Figure 3 while other rest of isolates $\mathrm{OD}(01,03-10)$ showed partial activity which were not considered in our further study. Emulsification index of $>50 \%$ or more was considered as significantly positive emulsification activity. In our study, revealed that among twelve bacterial isolates, only OD02 exhibited $>70 \%$ positive emulsification activity with hexane, showed $57 \%$ positive emulsification activity with xylene, and $95 \%$ were miscible with oil (petrol) Figure 4. Meanwhile, $\mathrm{OD}(01,03-10)$ of the isolates exhibited partial emulsification with 3 hydrocarbons tested.

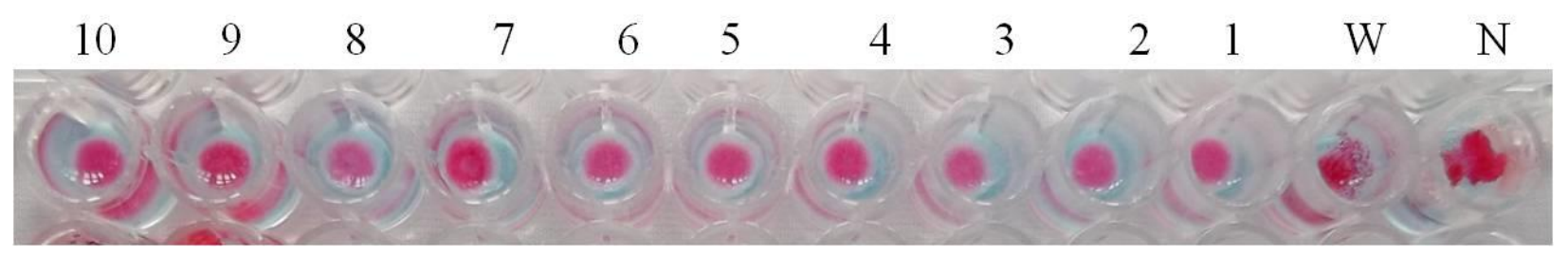

Figure 1. Penetration assay test for the screening of potential biosurfactant bacteria. Lane 1-10 randomly isolated suspected biosurfactant bacteria, W- Water, N-Negative control.

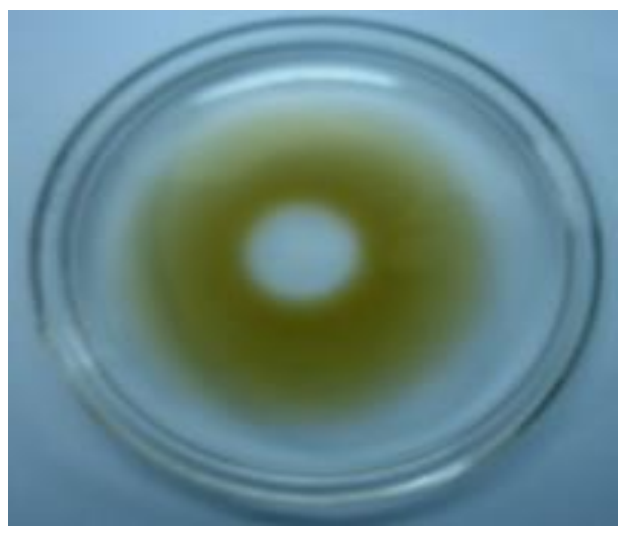

Figure 2. Oil displacement test with OD02 culture filtrate 


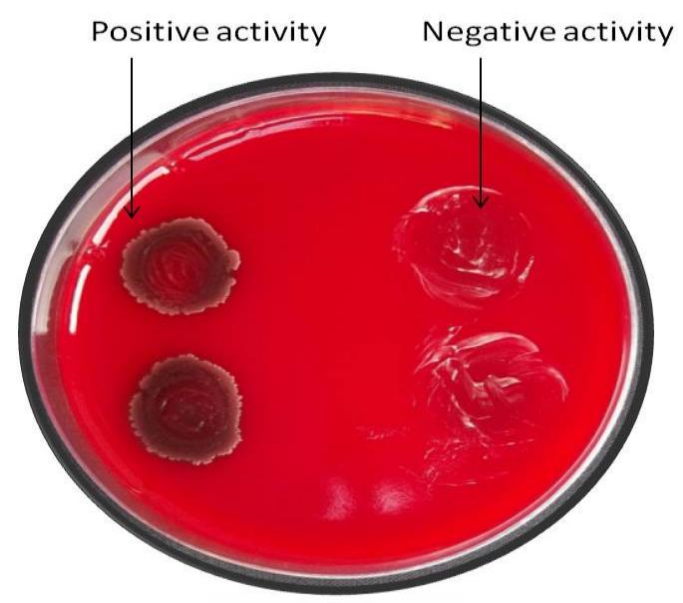

Figure 3. Haemolytic activity test, with OD02 bacteria.

Partial

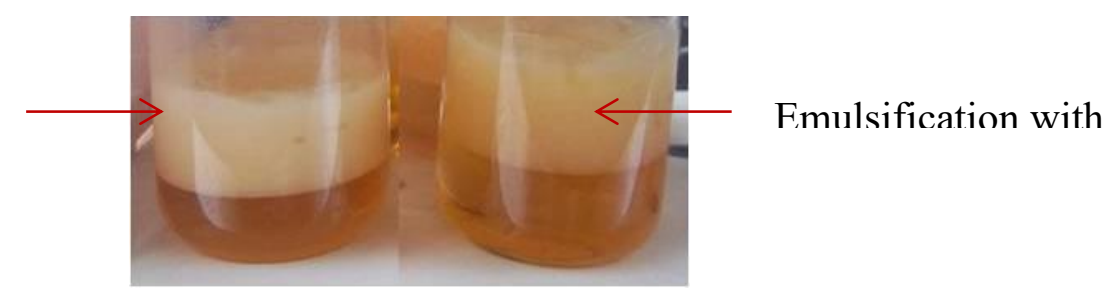

Figure 4. Emulsification assay test

\section{Isolation, purification and identification of pathogen}

Naturally infected potato tubers were collected from the agricultural field at Aligarh-Hathras region in 2017 for isolation and purification of the causal fungus in the laboratory. Cultures were purified by single hyphal tip method and were maintained on PDA at $28 \pm 2^{\circ} \mathrm{C}$ (Figure 5). The isolated fungi were identified on the basis of following morphological characteristics. The genus $R$. solani belongs to form Class Deuteromycetes that does not make vegetative spores and present as mycelium and sclerotia. It produces shade of brown hypha, constriction at the point of branching and right angle branching in matured hyphae. Sclerotia were undifferentiated aggregations of thick-walled cells, small (1-3-mm diameter) irregular-shaped, brown to black structures (Guttierez et al 1997). Similar result on isolation, purification and identification were reported by Parmeter and Whitney (1970), Domand and Flentje (1970). White cottony raised mycelia growth observed in Potato Dextrose Agar medium.

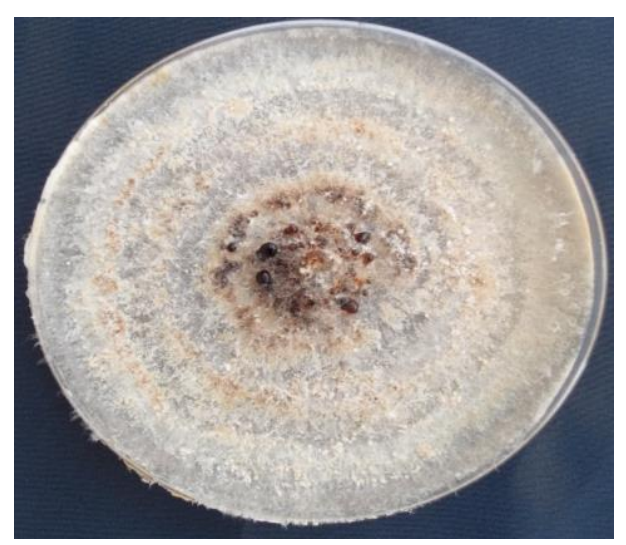

Figure 5. $R$. solani isolated from potato tuber skin. 
PCR based method identification

Results obtained from sequencing showed that atypical better bacterial OD02 belongs to genus Bacillus later named as Bacillus subtilis HussainT-AMU (NCBI Accession No. LC385950) (Figure 6).

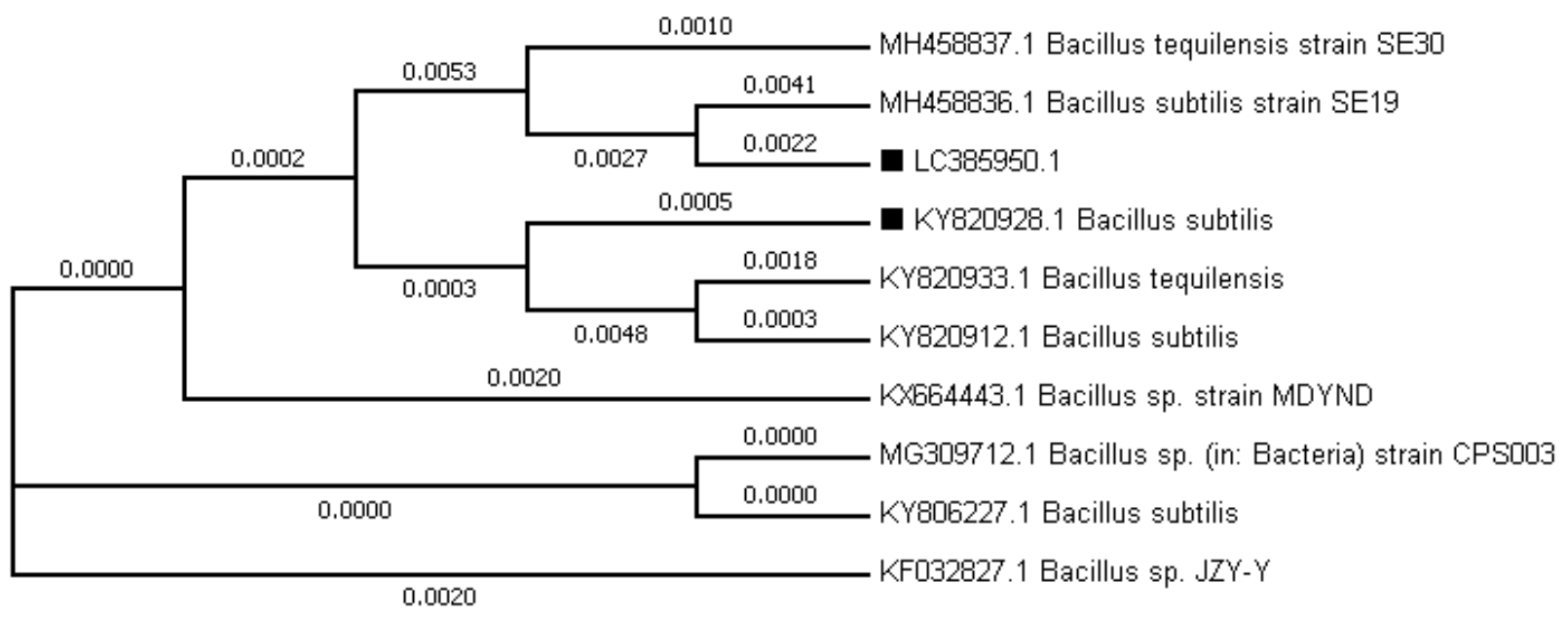

Figure 6. Phylogenetic tree relationship between B. subtilis HussainT-AMU and other Bacillus species.

Thin Layer Chromatography

The sediment obtained was placed in the TLC plate and the plates when sprayed with Ninhydrin reagent (95Ethanol $+5 \mathrm{H}_{2} \mathrm{SO}_{4}+1 \mathrm{gm}$ Ninhydrin reagent) and dried for $10 \mathrm{~min}$ in hot air oven at $100^{\circ} \mathrm{C}$. The plate showed red-pink spots indicating the presence of lipopeptides class of biosurfactants in the extract (Figure 7).

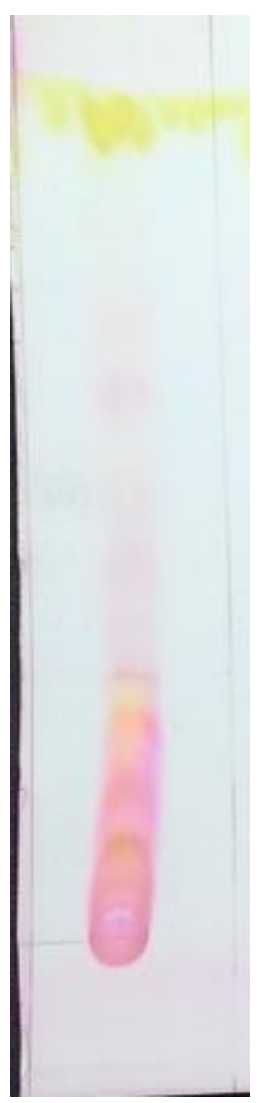

Figure 7. Chemical characterization of metabolite produced by B. subtilis HussainT-AMU through Thin Layer Chromatography. 
Inhibitory effect of $B$. subtilis HussainT-AMU on the growth of $R$. solani in dual culture and Food poisoning method

B. subtilis HussainT-AMU was tested for its bio-efficacy against $R$. solani using dual culture method. The new Bacillus strain significantly reduced the growth of pathogen $(45 \pm 0.30 \%)$, in comparison to control (Figure 8). Pathogen could not grow well in the presence of bacterial secondary metabolites. There was a significant difference between the bacterial treatments to \% inhibition of fungal radii. Growth of $R$. solani was significantly inhibited by the by antagonistic bacteria tested. 59.60\% inhibition of fungal radii was exhibited by B. subtilis HussainT-AMU strain most efficiently. Our result revealed that the culture filtrate was effective and significantly inhibiting the growth of R. solani at concentration of $3 \%$ and above (Figure 9).

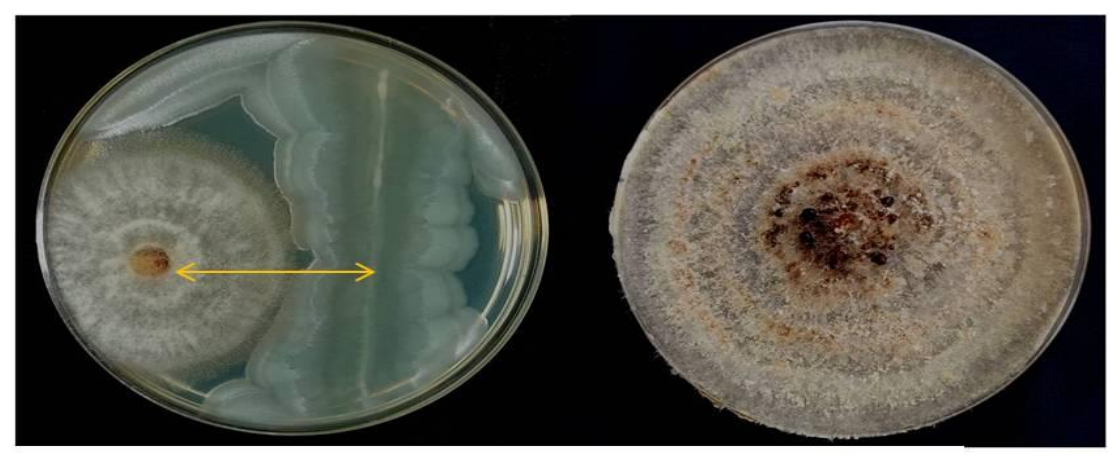

Treatment

Control

Figure 8. Dual culture assay with $R$. solani with $B$. subtilis HussainT-AMU.

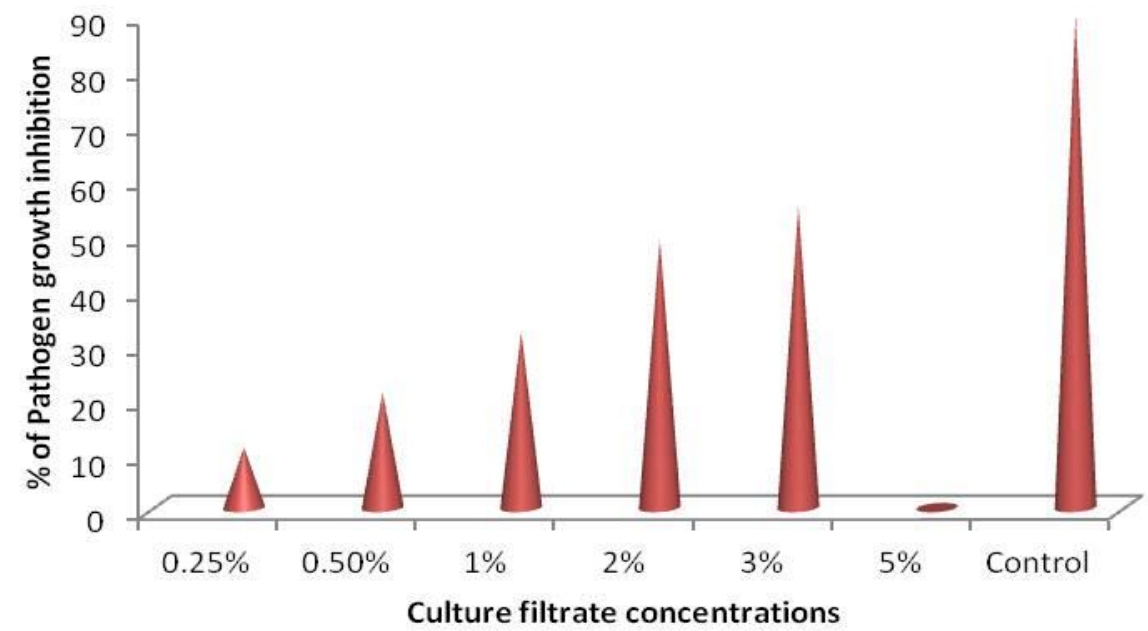

Figure 9. Pathogen (R.solani) growth inhibition by B. subtilis HussainT-AMU under food poisoning method

\section{DISCUSSION}

Both soil-borne and tuber-borne inoculum of $R$. solani is important in disease on potato (Frank and Leach 1980, Demirci 2011). Present chemical and cultural control methods have reduced the soil-borne and tuberborne inoculum, although research has been directed toward the use of antagonists for biocontrol of black scurf on potato. In the present study, rhizosphere associated bacteria was evaluated for its antagonism against $R$. solani, causative agent of potato black scurf. Biosurfactants are amphipathic compounds which contain hydrophobic and hydrophilic moieties that reduce surface tension and interfacial tension between individual molecules at the surface and the interface. 
Biosurfactant are known to have good penetration ability (Youssef et al 2004). Ability of some strains to show positive biosurfactant production following one method and negative following other methods makes it very difficult to confirm biosurfactant production using two or three methods. In view of this, several screening methods were considered in order to identify the potential organism that could produce biosurfactant. Compared to other isolates OD-02 exhibited good potential activity in the entire screening test for biosurfactant production activity. Hence, it was chosen as promising bacteria for further experimental study. Penetration method relies on the phenomenon of silica gel entering the hydrophilic phase from hydrophobic paste much more quickly in the presence of biosurfactants which leads to a colour change (Walter et al 2010). Biosurfactant free supernatant was turned cloudy but stayed red in comparison to OD02 isolate. The oil spreading method is rapid and easy to carry out, requires no specialized equipment, and only requires a small volume of sample (Plaza et al 2006). In our study, only OD02 was found to be positive by oil-spreading method indication production of biosurfactant. Displacement of oil clearly is a sign of extracellular surfactants present in the supernatant of cultures that is in compliance with our study also. Haemolytic activity appears to be a good screening criterion in the search for biosurfactant-producing bacteria (Carter 1984; Hussain and Khan, 2018). The haemolytic activity of biosurfactants was first discovered when Bernheimer and Avigad (1970) reported that the biosurfactant produced by B. subtilis, surfactin, lysed red blood cells. Blood agar lysis has been used to quantify surfactin (Moran et al 2002). This test is generally carried out as a primary method for screening of biosurfactant-producing bacteria. Isolates were tested for haemolytic activity, which is regarded by some authors as indicative for biosurfactant production and used as a preliminary method for bacterial screening that was in agreement with previous findings (Mulligan et al 1984, Carrillo et al 1996, Banat et al 2000, Zhang et al 2012, 2016). To determine the potential of a good biosurfactant emulsification activity is one of the good criteria (Bonilla et al 2005). In the present investigation OD01, 03-10 isolates showed partial emulsification potential, and only OD02 isolate gave a good emulsification index $>50 \%$ ) with all 3 hydrocarbons tested, which included hexane, xylene, and oil (petrol). Sequencing of 16S rRNA allows the accurate identification of bacterial genera from various microbes species. Bacillus is an important bacteria genus because of the synthesis of a wide range of metabolites with diverse properties (Jacobsen et al 2004, Velmurugan et al 2009). The 16S rRNA sequence analysis, and the high similarity $99 \%$ values confirmed that new Bacillus belong to the same species (Liu et al 2014) respectively, of which the phylogenetic tree is given in Figure 6. The precise definition of species and subspecies analysis of other genes is needed (Chun and Bae 2000). Minaxi and Saxena, (2010) observed that the inhibition of various pathogens viz., Colletotrichum trancatum, Drechslera graminea, Fusarium oxysporum, F. solani, M. phaseolina, Rhizopus arrhizus and Sclerotium rolfsi with P.aeruginoas RM-3 under dual culture method. The antagonistic activities of Pseudomonas sp. Bacillus sp. were showed positive inhibition of mycelial growth of $P$. infestans, Fusarium spp and $R$. solani under in vitro that is in agreement with previous findings of Tomar et al 2014, Hussain and Khan 2018a, Hussain et al 2019. Ahmadzadeh et al 2004 reported that antagonistic rhizobacteria, more specifically fluorescent pseudomonads and certain Bacillus species possessed the ability to inhibit fungal and bacterial root diseases of agricultural crops. Mycelial growth was completely inhibited, when the volume of the culture filtrate increased. The level of reduction was being of very low (below 3\%). However, Minaxi and Saxena, (2010) reported that P. aeruginosa strain RM3 was effective for inhibiting the growth of $M$. phaseolina and Dreschlera graminaeat 3\%. Some researchers have found that $B$. subtilis showed significant inhibitory effects on the growth of $R$. solani by reduced disease incidence and promoted plant growth (Calvo et al 2010, Khedher et al 2015, Hussain and Khan 2020, Khan et al 2020).D'aes et al (2011) reported that biocontrol research on biosurfactant has predominantly focused on the control of zoospore-producing plant pathogen, such as Pythium and Phytophthora spp. where the mode of action lies in zoospore lysis. Only a few studies have demonstrated the involvement of biosurfactant in biological control of non-zoospore producing plant pathogen which did not produced any positive response. They also reported that among the great variety of beneficial bacteria and metabolites already discovered, their attention has been focused on lipopeptides and the biosurfactant produced by Bacillus spp. The ability of different Bacillus species to prevent several plant diseases has resulted in the commercial development and registration of several Bacillus pest management bioproducts that can be integrated into pest management regimens to efficiently control plant diseases. Some potato varieties differ in their susceptibility to Rhizoctonia; however, no resistant varieties are currently available. To date no variety has been found with immunity 
to the sprout nipping and stem lesion phase, although some varieties show varying degrees of resistance to formation of sclerotia on tubers. Tuber inoculum is more important than the soil inoculum as the primary cause of disease. It is very important to develop fast and efficient methods to select biocontrol microorganisms, especially when evaluating a large number of candidates. In vitro evaluations allow for a reduction in the number of isolates, which makes further in vivo tests viable. Hence, it was reconfirmed in our research work also that only a very good control of $R$. solani fungus was observed by particular strain of B. subtilis HussainT-AMU and its metabolite can be very effective for the integrated diseases management of the plant pathogens in near future.

\section{ACKNOWLEDGEMENTS}

The First author is very thankful to Science and Engineering Research Board, Department of Science and Technology, New Delhi, Govt. of India, for providing the financial grants received under File No. DST-SERBNPDF/2016/001409/LS and Department of Botany, Aligarh Muslim University, Aligarh, for proving all the support and infrastructure facility. None of the author has any potential conflicts of interest.

\section{REFERENCES}

Ahmed AS, M Ezziyyani, C Pérez Sánchez, and MzzE Candela. 2013. Effect of chitin on biological control activity of Bacillus spp. and Trichoderma harzianum against root rot disease in pepper (Capsicum annuит) plants. European Journal of Plant Pathology 109:6:633-637.

Arora RK.2012. Eco-friendly management of soil and tuber borne diseases of potato. Indian Phytopathology 65:116-21.

Arora RK.2005. Efficacy of boric acid spray for control of black scurf in unwashed and washed potato tubers. Potato J 32:183-184.

Anjaiah V, N Koedam, B Nowak-Thompson, JE Loper, M Hofte, JT Tambong and P Cornelis. 1998. Involvement of phenazines and anthranilate in the antagonism of Pseudomonas aeruginosa PNA1 and Tn5 derivatives toward Fusarium spp. and Pythium spp. Mol Plant Microbe Interact 11:847-854.

Anandaraj B, P Thivakaran.2010. Isolation and production of biosurfactant producing organism from oil spilled soil. J. Biosci. Technol. 1(3): 120-126.

Ahmadzadeh M, AS Tehrani and KT Jahromi. 2004. Study on production of some antimicrobial metabolites by fluorescent pseudomonads. Iranian J. Agric. Sci., 35(3): 731-739.

Bakali, AM EL, MP Martin.2006.Black scurf of potato. M y c o 1 o g i s t. 2 0:130 - 132

Bernheimer AW, LS Avigad.1970.Nature and properties of a cytological agent produced by Bacillus subtilis. J Gen Microbiol 61:361-369

Baker K, R Cook.1974. Biological control of plant pathogens. W.H freeman Company, San Francisco, USA, p.433.

Banat IM, Makkar RS, Cameotra SS.2000. Potential commercial Application of Microbial Surfactants. Applied Microbiol. Biotechnol 53:495-508.

Bonilla M, C Olivaro, M Caronal, A Vazquez, M Soubes.2005. Production and characterization of a new bioemulsifier from Pseudomonas putida ML2. J Appl Microbiol 98:456-463.

Carter G.1984. Diagnostic Procedures in Veterinary Bacteriology and Mycology,4th ed. Springfield, IL, USA: Charles C Thomas.

Carrillo P, C Mardaraz, IS Pitta-Alvarez, AM Giulietti.1996. Isolation and selection of biosurfactant-producing bacteria. World Journal of Microbiology and Biotechnology 12:82-84.

Calvo E. Ormeño-Orrillo, E. Martínez-Romero, and D. Zúñiga.2010. Characterization of Bacillus isolates of potato rhizosphere from Andean soils of Peru and their potential PGPR characteristics, Brazilian Journal of Microbiology 41: 4 899-906.

Chun J, KS Bae. 2000. Phylogenetic analysis of Bacillus subtilis and related taxa based on partial gyrA gene sequences. Anton Van Leeuw J Microbiol.78:123-127.

Dodman, R. and Flentje, M. T. 1970. The mechanisms and physiology of plant penetration by Rhizoctonia solani. In : Parmeter, J. R. Jr. (ed.). Rhizoctonia solani : Biology and Pathology. University of California Press, Berkeley, USA.149-160.

Demirci E, E Dane, C Eken.2011.In vitro antagonistic activity of fungi isolated from sclerotia on potato tubers against Rhizoctonia solani. Turk J Biol 35:457-462.

D'aes J, GKH Hua, K De Mayer, J Pannecoucque, I Forrez, M Ongena, LEP Dietrich, LS Thomashow, DV Mavrodi and M Hofte.2011. Biological control of Rhizoctonia root rot on bean by phenazine and cyclic lipopeptide-producing Pseudomonas CMR12a. Phytopathology 101:996-1004. 
Durak E.2016. Biological Control of Rhizoctonia solani on potato by using indigenous Trichoderma spp. AIP Conference Proceedings 1726, 020020.

Errampalli D and HW Johnston.2001. Control of tuber-borne black scurf (Rhizoctonia solani) and common scab (Streptomyces scabies) of potatoes with a combination of sodium hypochlorite and thiophanatemethyl preplanting seed tuber treatment. Can. J. Plant Pathol. 23:68-77.

Frank JA, Leach SS.1980.Comparison of tuberborne and soilborne inoculum in the Rhizoctonia disease of potato. Phytopathology 70: 51-53

Geisslera M, C Oelligb, K Mossa, W Schwackb, M Henkela, R Hausmann.2017. High-performance thin-layer chromatography (HPTLC) for thesimultaneous quantification of the cyclic lipopeptides Surfactin, Iturin A and Fengycin in culture samples of Bacillus species. Journal of Chromatography B, 1044-1045:214-224.

Guttierez, W. A., Shew, H. D., and Melton, T. A. 1997. Sources of inoculum and management of Rhizoctonia solani damping-off on tobacco transplants under greenhouse conditions. Plant Dis., 81:604-606.

Gokte N, Swarup G (1988) On the potential of some bacterial biocides against root knot nematode 666 and cyst nematodes. Indian J Nematol 18:152-153 Gokte N, Swarup G (1988) On the potential of some bacterial biocides against root knot nematode 666 and cyst nematodes. Indian J Nematol 18:152-153

Gokte N, G Swarup.1988. On the potential of some bacterial biocides against root-knot and cyst nematodes. Indian Journal of Nematology. 18:152-153.

Grover RK and JD Moore.1962. Toximetric studies of fungicides of brown rot organism Sclerotinia fruticola and S. laxa. Phytopathology 52:876-880. https://extension.umaine.edu/publications/wpcontent/uploads/sites/52/2020/06/2273-reviewed-2020.pdf

Hussain A, MS Awan, SW Khan, MAS Ali, QAA AlI .2014. Bioefficacy of botanical extracts and bioagents against sclerotial isolates of Rhizoctonia solani. J Biodiv Envir Sciences. 4: 370-380.

Hussain T, M Haris, A Shakeel, AA Khan, MA Khan.2020a.Bio-nematicidal activities by culture filtrate of Bacillus subtilis HussainT-AMU: new promising biosurfactantbioagent for the management of Root Galling caused by Meloidogyne incognita. Vegetos 33:229-238

Hussain T and AA Khan.2020.Bacillus subtilis HussainT-AMU and its antifungal activity against Potato black scurf caused by Rhizoctonia solani. Biocatalysis and Agricultural Biotechnology.23:101433.

Hussain T and AA Khan.2018.A combination of rapid and easy assays of biosurfactant producing bacteria strain isolated from automobiles repairing workshop in Aligarh. Proceedings of the Voronezh State University of Engineering Technologies 80(3):153-163.

Hussain T and AA Khan.2018a.Biological control of black scurf of potato caused by Rhizoctonia solani using lipopeptides produced by novel biosurfactant bacteria: Bacillus subtilisHussainT-AMU isolated from Paradwip port, Odisha, India. National Conference on Biointensive Approaches in Plant Protection Strategies and their Socio-economic impacts held on 29th-30th Oct. 2018 at Dept. of Plant Protection, Aligarh Muslim University, Aligarh, India under Indian Phytopathological society, Mid-Eastern Zone region Annual meeting. OP, pp 31.

Hussain T, AA Khan and S Tomar. 2019.Biocontrol of dry rot of potato seed tubers caused by Fusarium sp. by using novel biosurfactant bacteria Bacillus firmus HussainT-AMU: Lab.66 producing cyclic lipopeptides. Indian Plant science Congress 2019, from 23rd to 25th Jan.2019 at SRM Institute of Science and Technology, Kattankulathur, TN.pp.101.

Jacobsen BJ, NK Zidack, BJ Larson.2004. The role of Bacillus-based biological control agents in integrated pest management systems: plant diseases. Phytopathology 94: 1272-1275.

Juan-Abgona RV, N Katsuno, K Kageyama, M Hyakumachi.1996. Isolation and identification of hypovirulent Rhizoctonia spp. from soil. Plant Pathol, 45: 896-904.

Khan MA, S Tomar and T Hussain.2020.Efiicacy of biosurfactant producing bacteria against fungal disease of potato.4th IUPAC International Conference on "Agrochemicals Protecting Crops, Health and Natural Environment -Discovery and development of synthetic and natural products for health and pests management" (APCHNE-2020) being organized by Department of Chemicals \& Petrochemicals, Society for Promotion of Sustainable Agriculture (SPSA) and Institute of Pesticide Formulation Technology, Gurugram, during 7-10 January 2020, in New Delhi, India. pp.16.

Khurana SMP, SK Pandey, RL Bhale, BK Patel and BS Lakra.1998. Surveillance for potato diseases in India over last five years. Indian Journal of Potato Association 25 : 16-20.

Khedher SB, O Kilani-Feki, M Dammak, H Jabnoun-Khiareddine, M Daami-Remadi, and S Tounsi.2015. Efficacy of Bacillus subtilis V26 as a biological control agent against Rhizoctonia solani on potato, Comptes Rendus Biologies 338: 12:784-792.

Kiewnick S and RA Sikora.2006. Biological control of the root-knot nematode Meloidogyne incognita by Paecilomyces lilacinus strain 251. Biol. Control 38:179-187.

Kavitha PG, EI Jonathan and S NakkeeraN.2012. Effects of crude antibiotic of Bacillus subtilis on hatching of eggs and mortality of juveniles of Meloidogyne incognita. Nematol. Medit 40:203-206. 
Liu HL, YY Li, RC Ju, and HT Zhao.2014. Isolation, identification and fermentation optimization of antagonistic Bacillus subtilis KC-5, China Biotechnology, 34:96-102.

Miller JH. 1972. Experiments in Molecular Genetics.Cold Spring Harbor Laboratory Press, Cold Spring Harbor, N.Y., p. 433.

Moran A, Alejandra M, Martinez F et al.2002.Quantification of surfactin in culture supernatant by hemolytic activity. Biotechnol Lett 24:177-180.

Morikawa, M, H Diado, T Takao, S Murata, Y Shimonishi, T Imanaka.1993. A new lipopeptide biosurfactant produced by Arthrobacter sp. strain MIS38. J Bacterio. 175: 6459-6466.

Morikawa, M, Y Hirata, T Imanaka.2000. A study on the structure function relationship of lipopeptide biosurfactants. Biochim Biophys Acta 1488:211-218.

Minaxi and Saxena, J.2010. Characterization of Pseudomonas aeruginosa RM-3 as a potential biocontrol agent. Mycopathologia, 170 (3):181-193.

Mohsin T, Y Sumera and HY Fauzia. 2010. Biological control of Potato Black scurf by Rhizosphere associated Bacteria. Brazalian Journal of Microbiology. 41:439-451.

Mendez J. 2014. Characterization of phosphate-solubilizing bacteria isolated from the arid soils 523 of a semidesert region of north-east Mexico. Biol Agric Hortic 30:211-217.

Mulligan CN, DG Cooper, RJ Neufeld.1984. Selection of microbes producing biosurfactants in media without hydrocarbons. J. Ferment. Technol. 62:311-314.

Parmeter J R Jr and HA Whitney. 1970. Taxonomy and nomenclature of the imperfect state. In Parameter, I. R. Jr. (ed.) Rhizoctonia solani, Biology and Pathology, London, Berkeley CA: University of California Press. 7-19.

Plaza G, I Zjawiony, I Banat.2006. Use of different methods for detection of thermophilic biosurfactant-producing bacteria from hydrocarbon-contaminated bioremediated soils. J Petro Science Eng. 50:71-77.

Prasad CS, V Gupta.2002. Studies on bio efficacy of Trichoderma harzianum in management of stem rot of potato (Rhizoctonia solani). Natl Acad Sci Lett 25:357-359.

Pusey PL, MW Hotchkiss, HT Dulmage, RA Banumgardner, EI Zehr.1988. Pilot tests for commercial production and application of Bacillus subtilis (B-3) for postharvest control of peach brown rot. Plant Disease 72:622626.

Pusey PL, CL Wilson.1984.Postharvest biological control of stone fruit brown rot by Bacillus subtilis. Plant Disease 68:753-756.

Raaijmakers JM, I de Bruijn and MJD de Kock.2006. Cyclic lipopeptide production by plant-associated Pseudomonas species: diversity, activity, biosynthesis and regulation. Mol Plant Microbe Interact 19:699710 .

Sharma S.2015.Black Scurf and stem canker. In A manual on diseases and pest of potato-Technical Bulletin No. 101 (Ed. BP singh, M Nagesh, Sanjeev Sharma, Vinay Sagar, A Jeevvlatha and J Sridhar) ICAR-central potato research institute, Shimla, HP, India. 2015. pp. 11-13.

Sharma BL and HS Sohi.1965. Control of black scurf diseases of potato in Himachal Pradesh. Indian Potato J 7:12-17.

Shoeb E. 2006. Genetic Basis of Heavy Metal Tolerance in Bacteria. Ph.D. thesis. University of Karachi, Karachi, Pakistan.

Satpute SK, BD Bhawsar, PK Dhakephalkar, BA Chopade. 2008. Assessment of different screening methods for selecting biosurfactant producing marine bacteria. Indian J Marine Sci. 37:243-250.

Stanghellini ME and RM Miller.1997. Biosurfactants: their identity and potential efficacy in the biological control of zoosporic plant pathogens. Plant Diseases 81:4-12.

Somani AK.1986. Non-hazardous chemical control of black scurf of potato. Indian J.Agric. Sci, 56:366-369.

Szczech and M Shoda.2006. The effect of mode of application of Bacillus subtilis RB14-C on its efficacy as a biocontrol agent against Rhizoctonia solani, Journal of Phytopathology, 154(6):370-377.

Tambong JT and Ho"fte, M.2001. Phenazines are involved in biocontrol of Pythium myriotylum on cocoyam by Pseudomonas aeruginosa PNA1. Eur J Plant Pathol 107:511-521.

Tomar S, BP Singh, M Lal, MA Khan, T Hussain, S Sharma, SK Kaushik and S Kumar.2014. Screening of novel microorganism for biosurfactant and biocontrol activity against Phytophthora infestans. Journal of Environmental Biology, 35:893-899.

Vincet JM.1927.Distortion of fungal hyphae in the presence of certain inhibitors. Nature, 159:850.

Velmurugan N, MS Choi, SS Han, YS Lee. 2009. Evaluation of antagonistic activities of Bacillus subtilis and Bacillus licheniformis against wood-staining fungi: in vitro and in vivo experiments. J Microbiol 47:385392.

Walter V, Syldatk, C, R Hausmann.2010. Screening concepts for the isolation of biosurfactant producing microorganisms. Adv Exp Med Biol 672:1-13.

Youssef NH, KE Duncan, DP Nagle, KN Savage, RM Knapp, MJJ McInerney .2004.Comparison of methods to detect biosurfactant production by diverse microorganisms. Microbiol Methods 56 (3):339-347. 
Zhang J, Q Xue, H Gao, H Lai, P Wang.2016. Bacterial degradation of crude oil using solid formulations of Bacillus strains isolated from oil-contaminated soil towards microbial enhanced oil recovery application. RSC Advances 6 (7):5566-5574.

Zhang X, D Xu, C Zhu, T Lundaa, KE Scherr.2012. Isolation and identification of biosurfactant producing and crude oil degrading Pseudomonas aeruginosa strains. Chemical Engineering Journal 209:138-146.

||-------|||-------|| 